\title{
PENGARUH SUHU EKSTRAKSI TERHADAP RENDEMEN DARI ECENG GONDOK (Eichornia Crassipes)
}

\section{The Influence Of The Extraction Temperature On The Rendemen Of Waterhycinth (Eichornia Crassipes)}

\author{
Fahrunnisaa $^{* 1}$, Sinardi $^{2}$, A.Sry Iryani ${ }^{3}$ \\ 1.2.3Teknik Kimia, Fakultas Teknik, Universitas Fajar \\ Jln. Prof Abdurrahman Basalamah No.101 Makassar, 90231
}

*Email : Neesza@ymail.com

\begin{abstract}
ABSTRAK
Penelitian ini bertujuan untuk mengetahui pengaruh suhu ekstraksi terhadap rendemen dan kadar metoksil dengan variabel suhu 60,70 , dan $80^{\circ} \mathrm{C}$ serta menentukan suhu optimal ekstraksi. Tahap penelitian terdiri dari ekstraksi, pengendapan, pencucian, dan pengeringan. Pektin yang dihasilkan dianalisa dengan menambahkan akuades, etanol $96 \%$, dan $\mathrm{NaOH}$, kemudian dilakukan identifikasi senyawa-senyawa yang terkandung menggunakan spektrofotometer gas kromatografi. Selain itu, dilakukan juga analisis kualitatif dan kuantitatif yang membuktikan bahwa hasil ekstraksi menghasilkan pektin, yaitu ditandai dengan adanya endapan berupa gel bening. Hasil rendemen pektin dengan suhu 60,70 , dan $80^{\circ} \mathrm{C}$ adalah 0,49\%, 0,61\%, dan 0,77\%. Sedangkan, hasil analisa kadar metoksil adalah 3,85\%, 3,18\%, dan 4,47\%.
\end{abstract}

Kata Kunci : Ekstraksi, Pektin, Kadar Metoksil.

\begin{abstract}
The purpose of this research is to find out the influence of the extraction temperature on the rendement and pectin methoxyl contents with applied temperatures ranged from 60,70 , and $80^{\circ} \mathrm{C}$ and find out optimum temperature for extraction. The stages of this research involve extraction, precipitation, washing, and drying. The pectin product was, then analysed by reacting it with aquadest, ethanol $96 \%$, and $\mathrm{NaOH}$. And then identified the contents of pectin by Gas Chromatography Mass Spectrofotometer. From the qualitative and quantitative tested, pectin was produced and this is shown by the gelformation. The rendements produced with extraction temperatures of 60,70 , and $80{ }^{\circ} \mathrm{C}$ were $0,49 \%, 0,61 \%$, and $0,77 \%$. While its methoxyl contents were $3,85 \%, 3,18 \%$, and $4,47 \%$.
\end{abstract}

Keywords: Extraction, Pectin, Methoxyl contents. 


\section{PENDAHULUAN}

Upaya yang biasa dilakukan oleh masyarakat untuk memberantas Eceng Gondok adalah dengan mengangkat Eceng Gondok tersebut dari lingkungan perairan dan dibiarkan mengering. Namun ada juga yang memanfaatkannya sebagai bahan baku kerajinan tangan. Menurut Sugesti ([1]). Eceng Gondok mengandung pektin sebesar $7,2 \%$ sehingga eceng gondok juga dapat digunakan sebagai bahan baku pembuatan pektin.

Eceng Gondok hidup tingginya 0,4 - 0,8 meter. Tidak mempunyai batang. Daunnya tunggal dan berbentuk oval, ujung dan pangkalnya meruncing, pangkal tangkai daun mengelembung. Permukaan daunnya licin dan berwarna hijau. Bunganya termasuk bunga majemuk, berbentuk bulir, kelopaknya berbentuk tabung. Bijinya berbentuk bulat dan berwarna hitam. Buahnya kotak beruang tiga dan berwarna hijau. Akarnya merupakan akar serabut ([2]). .

Pektin merupakan senyawa polisakarida yang terdapat pada dinding sel dari semua jaringan tanaman. Pektin mudah larut dalam air dan bila dipanaskan dengan penambahan gula serta asam akan menyebabkan terbentuknya gel. Sebagian besar pektin yang dihasilkan digunakan untuk pembuatan jam dan jeli. Dalam industri obat-obatan pektin digunakan sebagai bahan pencampur salep,pil,dan tablet. Dalam industri kosmetik, pektin digunakan sebagai bahan pencampur pembuatan krim, sabun, minyak dan pasta gigi. Walaupun pektin banyak digunakan dalam industri pangan dan non pangan,tetapi sampai saat ini Indonesia masih mengimpor dari luar negeri ([3]). Pemanfaatan Eceng Gondok sebagai bahan dasar produksi pektin berarti akan mengurangi impor pektin yang pada akhirnya dapat menghemat devisa negara.

Ekstraksi pektin dapat dilakukan secara biokimia dan kimia. Secara kimia pektin dapat diekstraksi dari jaringan tanaman dengan pemanasan dalam asam encer sedangkan ekstraksi secara biokimia dengan menggunakan enzim, dimana enzimenzim ini berperan pada degradasi hidrolitik dari subtansi pektin yang terdiri dari pektin metilesterase dan pektin poligalakturonase ([4]). 
Ekstraksi pektin secara kimia dapat dilakukan dengan cara mengekstraksi dari berbagai kulit buah-buahan segar dengan pemanasan pada suhu $90-95^{\circ} \mathrm{C}$ selama satu jam dalam asam encer pada $\mathrm{pH}$ 4,5 menggunakan asam yang sesuai seperti asam klorida. Pektin dalam filtrat diendapkan dengan menggunakan etanol $96 \%$ ([5]).

Lamanya waktu ekstraksi yang dilakukan mempengaruhi berat pektin yang didapat, semakin lama waktu ekstraksi yang dilakukan maka semakin besar pula berat pektin yang diperoleh dan kenaikan berat pektin sejalan dengan peningkatan suhu pada proses ekstraksi dilakukan. Pencucian pektin dengan alkohol menghasilkan jumlah pektin yang tidak terlalu jauh dengan pencucian tanpa menggunakan alkohol, namun pektin yang dihasilkan memberikan warna yang lebih baik yaitu putih kekuningan ([6]).

Pektin dapat diperoleh dari sumbernya melalui proses ektraksi dengan larutan asam yang dapat menghidrolisis protopektin menjadi pektin ([7]). Ekstraksi pektin dipengaruhi oleh suhu, lama ekstraksi dan $\mathrm{pH}$. Berdasarkan uraian diatas maka penting dilakukan penelitian tentang pengaruh suhu ekstraksi terhadap rendemen dan kadar metoksil dari Eceng Gondok.

Dalam penelitian ini terdapat beberpa masalah yaitu bagaimana karakterisasi biji Eceng Gondok, bagaimana pengaruh suhu ekstraksi terhadap rendemen,metoksil dan pektin, serta berapa suhu tertinggi ekstraksi dari Eceng Gondok .

Tujuan dari penelitian ini adalah mengetahui karakterisasi biji Eceng Gondok, mengetahui pengaruh suhu ekstraksi terhadap rendemen, metoksil dan pektin, mengetahui suhu optimal ekstraksi pektin dari Eceng Gondok.

\section{METODE PENELITIAN}

Metode penelitian terdiri dari bahan dan alat serta prosedur kerja 


\section{Bahan}

Bahan yang digunakan dalam penelitian ini yaitu serbuk eceng gondok (tanpa akar), $\mathrm{NaOH} 2 \mathrm{~N}: \mathrm{NaOH} 0,1 \mathrm{~N}: \mathrm{NaOH}$ 0,25 N, HCL 0,01 M, $\mathrm{C}_{2} \mathrm{H}_{5} \mathrm{OH} 96 \%$, akuades, Indicator fenolftalein, kertas indikator universal.

\section{Peralatan}

Alat yang digunakan dalam penelitian ini yaitu labu dasar bulat leher tiga, pendingin refluks, statif dan klem, kawat kasa, pengaduk kaca, neraca analitik, oven, tabung reaksi, pipet ukur, pisau, gelas ukur, gelas piala, erlemenyer, labu ukur, thermometer, kertas saring, buret, corong buchner, cawan porselen, corong kaca.

\section{Prosedur}

Prosedur penelitian terdiri dari persiapan bahan baku, ekstraksi bahan baku, dan analisa produk ekstraksi.

\section{Tahap Persiapan}

Eceng gondok (tanpa akar) dicuci hingga bersih dan dipotong-potong dengan pisau. Dikeringkan selama satu hari kemudian digiling hingga berbentuk serbuk dan diayak.

\section{Tahap Isolasi Pektin dari Eceng Gondok}

Serbuk Eceng Gondok ditimbang masing-masing sebanyak 25 gram lalu dimasukkan kedalam labu dasar bulat leher tiga. Larutan HCL 0,01 M sebanyak $1000 \mathrm{ml}$ dimasukkan kedalam labu dasar bulat leher tiga dan diektraksi pada suhu $60^{\circ} \mathrm{C}, 70^{\circ} \mathrm{C}, 80^{\circ} \mathrm{C}$. Hasil dari proses ektraksi disaring menggunakan kertas saring untuk memisahkan filtrat hasil ektraksi dengan residu. Filtratnya diambil dan residunya dibuang. 


\section{Rendemen}

Filtrat hasil ekstraksi ditambah dengan larutan Etanol 96\% (1:1) dan didiamkan selama 1 malam. Endapan yang dihasilkan dicuci dengan Etanol 96\% kemudian ditaruh dalam cawan porselen dan dikeringkan dalam oven pada suhu 60 - $62{ }^{\circ} \mathrm{C}$ selama \pm 3 jam. Pektin yang sudah kering kemudian ditimbang dengan menggunakan neraca analitis untuk mengetahui berat pektin kering. Hasil pektin kering (gram) dapat dihitung menjadi rendemen pektin.

\section{Kadar Metoksil}

Pektin seberat 0,1 gram dimasukkan dalam erlemenyer $250 \mathrm{ml}$ dan ditambah dengan $1 \mathrm{ml}$ etanol dan $20 \mathrm{ml}$ aquadest ditutup dan dikocok hingga pektin larut sempurna. Tambahan 3 tetes fenoftalein dan $\mathrm{NaOH} 0,1 \mathrm{~N}$ (yang sudah distandarisasi) sampai berubah warna menjadi warna merah muda seulas. Larutan

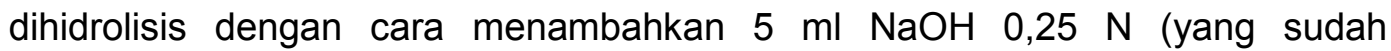
distandarisasi) dikocok dan didiamkan selama 30 menit pada suhu kamar.

Selanjutnya kedalam larutan ditambahkan larutan $\mathrm{HCL}$ 0,25 N sebanyak $5 \mathrm{ml}$. Titrasi dengan $\mathrm{NaOH} 0,1 \mathrm{~N}$ (yang sudah distandarisasi) hingga terjadi perubahan warna merah muda.

\section{HASIL DAN PEMBAHASAN}

\section{Karakterisasi Biji Eceng Gondok}

Dari hasil penelitian Eceng Gondok memiliki senyawa-senyawa yang terkandung, senyawa yang dominan adalah Dodecanoic Acid, 1,2,3-Propanetriyl Ester seperti. Dari hasil pemeriksaan GCMS terdapat 6 peak seperti pada Gambar 1 dan Tabel 1 


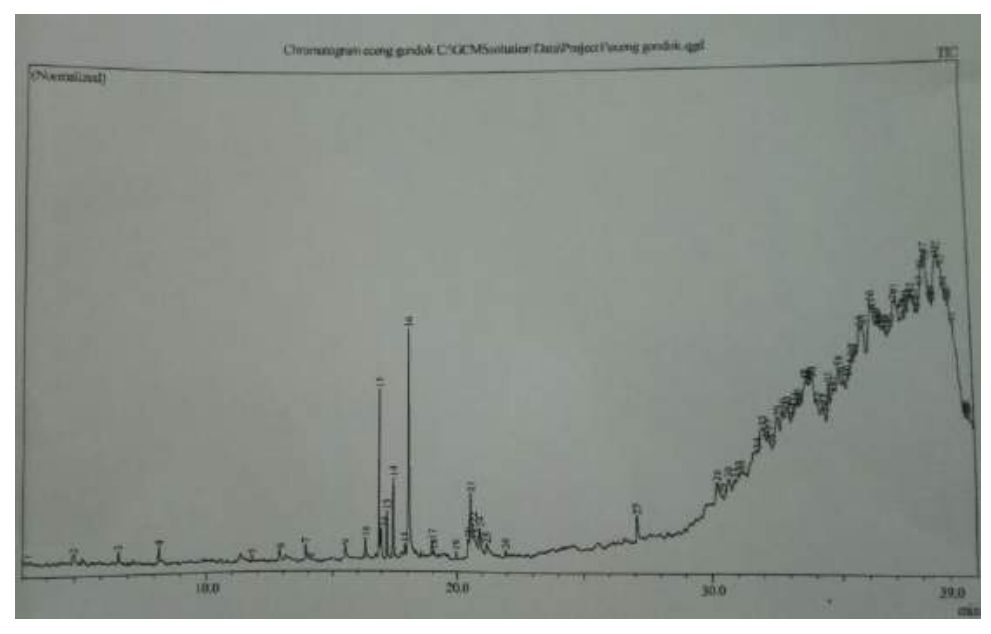

Gambar 1 Senyawa - senyawa Eceng Gondok

Tabel 1 Senyawa Eceng Gondok

\begin{tabular}{|c|c|c|c|c|}
\hline No & Peak & Nama Senyawa & $\begin{array}{c}\text { Rumus } \\
\text { Molekul }\end{array}$ & $\begin{array}{c}\text { Kadar } \\
\text { (\%) }\end{array}$ \\
\hline 1 & 11 & $\begin{array}{c}\text { 2-Hexadecen-1-OL, 3, 7, 11, 15- } \\
\text { TetraMethyl }\end{array}$ & $\mathrm{C}_{20} \mathrm{H}_{40} \mathrm{O}$ & 0,73 \\
\hline 2 & 16 & Hexadecanoic Acid, Methyl Ester & $\mathrm{C}_{17} \mathrm{H}_{34} \mathrm{O}_{2}$ & 1,75 \\
\hline 3 & 21 & 9 - Octadecanoic Acid, Methyl Ester & $\mathrm{C}_{19} \mathrm{H}_{38} \mathrm{O}_{2}$ & 0,53 \\
\hline 4 & 58 & 1- Chlorooctadecane & $\mathrm{C}_{18} \mathrm{H}_{37} \mathrm{C}_{1}$ & 2,58 \\
\hline 5 & 77 & Myristic acid vinyl ester & $\mathrm{C}_{16} \mathrm{H}_{30} \mathrm{O}_{2}$ & 2,62 \\
\hline 6 & 90 & $\begin{array}{r}\text { Dodecanoic acid,1,2,3- Propanetriyl } \\
\text { ester }\end{array}$ & $\mathrm{C}_{39} \mathrm{H}_{74} \mathrm{O}_{6}$ & 4,06 \\
\hline
\end{tabular}

Analisis Eceng Gondok dengan menggunakan Spektofotometer GC MS, maka kita dapat mengetahui senyawa - senyawa yang terkandung didalam tanaman Eceng Gondok yang paling dominan adalah Hexadecanoic acid kelompok Palmitat dan 2-hydroxy-1 Hexadecanoic acid. Asam palmitat dalam tanaman ini merupakan sumber vitamin A. Hexadecanoic Acid- Methyl Ester dengan \%Area 1.75, Dodecanoic Acid,1,2,3-Propanetriyl Ester dengan \% Area 4.06. dimana asam pektinat yang disebut juga dengan pektin, dalam molekulnya terdapat ester metal pada beberapa ester metal pada beberapa gugus karbosil sepanjang rantai polimer dari galakturonat. 


\section{Analisis Kualitatif}

Dalam penelitian ini produk yang dihasilkan merupakan pektin. Hal ini dapat ditunjukkan berdasarkan hasil uji kualitatif yaitu terbentuknya endapan bening seperti gelatin pada penambahan etanol 96\%. Pektin akan mengendap bila ditambahkan dengan alkohol. Hal ini sesuai dengan sifat pektin yang tidak dapat larut dalam pelarut organik seperti alkohol. Alkohol berfungsi sebagai pendehidrasi yaitu mengambil larutan air dari koloid pektin yang hidrofil dan menyebabkan terbentuknya gumpalan. Gumpalan tersebut ditunjukkan dengan terbentuknya gel bening pada larutan pektin.

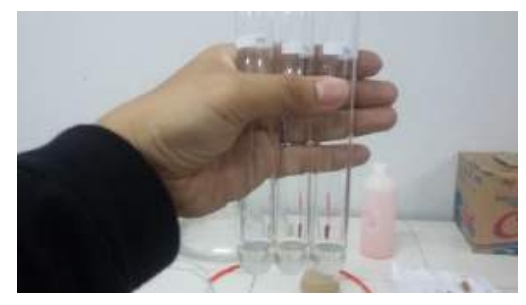

Gambar 2 Hasil Uji Kualitatif

\section{Pengaruh Suhu Terhadap Rendemen}

Dari hasil penelitian dan perhitungan rendemen diperoleh data seperti Tabel 2.

Table 2 Data Perhitungan Rendemen

\begin{tabular}{|c|c|c|}
\hline No & Suhu Ekstraksi & Rendemen \\
\hline 1 & $60 \circ \mathrm{C}$ & $0,49 \%$ \\
\hline 2 & $70 \circ \mathrm{C}$ & $0,61 \%$ \\
\hline 3 & $80 \circ \mathrm{C}$ & $0,77 \%$ \\
\hline
\end{tabular}

Hubungan antara suhu ekstraksi dengan rendemen dapat dilihat pada

\section{Gambar 2}




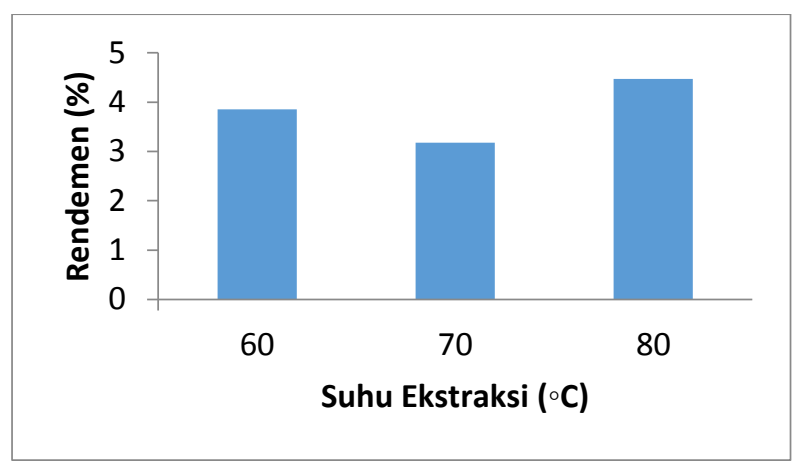

Gambar 3 Hubungan suhu ekstraksi dengan rata-rata rendemen

Dari Gambar 3 terlihat suhu ekstraksi sangat mempengaruhi rendemen yakni semakin tinggi suhu ekstraksi semakin tinggi nilai rendemen. Rendahnya rendemen yang diperoleh dari ekstraksi Eceng Gondok yaitu 0,49\% pada suhu $60^{\circ} \mathrm{C}$ dan $0,61 \%$ pada suhu $70^{\circ} \mathrm{C}$. Hal ini kemungkinan disebabkan senyawa pektin yang terdapat pada jaringan tanaman Eceng Gondok belum terhidrolisis secara optimal. Rendemen terus meningkat pada suhu ekstraksi $80^{\circ} \mathrm{C}$ sebanyak $0,77 \%$. Suhu yang tinggi selama hidrolisis akan meningkatkan rendemen yang dihasilkan. Hal ini disebabkan karena semakin tinggi suhu ekstraksi maka hidrolisis protopektin menjadi pektin akan meningkat. Protopektin merupakan senyawa pektat yang terdapat pada bagian hijau tanaman atau pada buah yang belum masak. Protopektin tidak larut didalam air karena kehadiran garam kalsium atau magnesium yang tidak larut. Penyebab lain ketidaklarutan protopektin adalah karena berikatan dengan selulosa atau beberapa polisakarida dengan berat molekul tinggi yang tidak larut. Protopektin dapat dibuat menjadi pektin yang larut dalam air dengan cara mengekstraksinya dalam larutan asam panas.

\section{Pengaruh Suhu Terhadap Kadar Metoksil}

Kadar metoksil merupakan faktor yang sangat berpengaruh terhadap kondisi pembentukan gel pektin. Penentuan kadar metoksil ini dilakukan dengan cara menghidrolisis gugus metoksil. 
Dari hasil penelitian dan perhitungan metoksil diperoleh data seperti Tabel 3.

Tabel 3 Data perhitungan metoksil

\begin{tabular}{|c|c|c|}
\hline No & Suhu Ekstraksi & Kadar Metoksil \\
\hline 1 & $60 \circ \mathrm{C}$ & $3,85 \%$ \\
\hline 2 & $70 \circ \mathrm{C}$ & $3,18 \%$ \\
\hline 3 & $80 \circ \mathrm{C}$ & $4,47 \%$ \\
\hline
\end{tabular}

Kemudian dilakukan titrasi asam basa. Hubungan antara rata - rata kadar metoksil $(\%)$ dengan suhu ekstraksi $\left({ }^{\circ} \mathrm{C}\right)$ dapat dilihat pada Gambar 3.

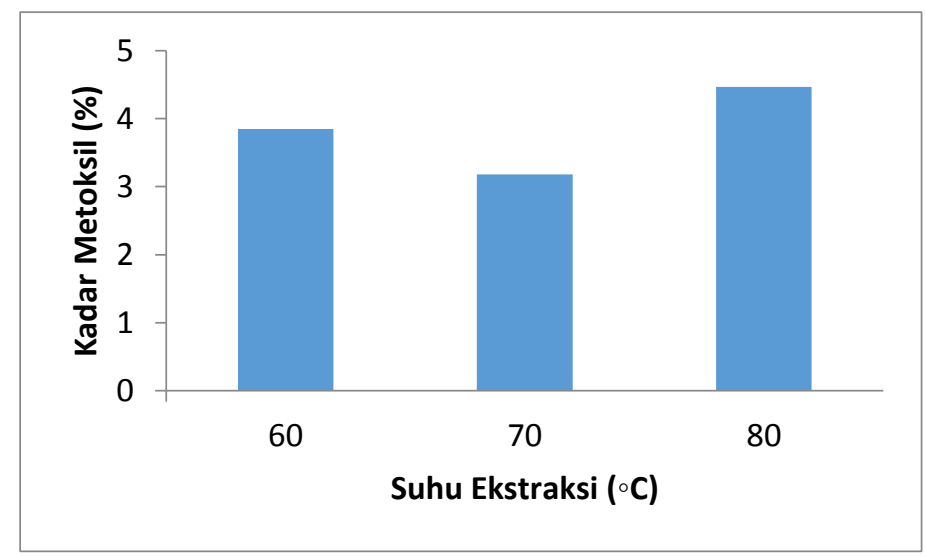

Gambar 4 Hubungan antara Suhu Ekstraksi dengan rata- rata Kadar Metoksil

Dari Gambar 4 data penelitian dapat diketahui bahwa kadar metoksil pektin pada suhu $60^{\circ} \mathrm{C}$ dan $70^{\circ} \mathrm{C}$ masih rendah. Ini disebabkan karena pektin belum terhidrolisis secara sempurna sehingga kadar metoksilnya masih rendah. Kadar metoksil pektin meningkat pada suhu ekstraksi yaitu $80^{\circ} \mathrm{C}$, pada suhu didapatkan kadar metoksil yang tertinggi. Jika suhu ekstraksi terlalu tinggi maka semua gugus metoksil akan terhidrolisis seluruhnya sehingga menghasilkan produk yang tidak larut dalam air dan tidak lagi membentuk gela yang disebut asam pektat. Oleh sebab itu, kuantitas dan kualitas pektin yang diperoleh tergantung pada penanganan kondisi ekstraksi yang meliputi suhu ekstraksi, waktu ekstraksi dan $\mathrm{PH}$. 
Berdasarkan data penelitian dapat dilihat bahwa kadar metoksil pektin eceng gondok kurang dari $7 \%$. Ini berarti pektin hasil penelitian ini termasuk pektin bermetoksil rendah.

\section{KESIMPULAN}

Dari hasil penelitian maka dapat disimpulkan bahwa:

1. Karakterisasi dari Eceng Gondok terdapat senyawa - senyawa diantaranya adalah Palmitic Acid,N- Octyl ester dengan \%Area 1,25, Hexadecanoic AcidMethyl Ester dengan \%Area 1,75, Dodecanoic Acid,1,2,3-Propanetriyl Ester dengan \% Area 4,06. Terbentuknya gumpalan atau gel bening menandakan adanya pektin pada Eceng Gondok.

2. Suhu ekstraksi terhadap rata-rata rendemen, metoksil hasil ekstraksi Eceng Gondok berbeda-beda. Makin tinggi suhu ekstraksi makin banyak rendemen, metoksil yang dihasilkan. Rendemen tertinggi pada suhu ekstraksi $80^{\circ} \mathrm{C}$ yaitu sebesar $0,77 \%$ dan metoksil tertinggi pada suhu ekstraksi $80^{\circ} \mathrm{C}$ yaitu sebesar $4,47 \%$.

3. Suhu tertinggi yang dihasilkan pada proses ekstraksi Eceng Gondok penelitian ini adalah $80^{\circ} \mathrm{C}$, dan berdasarkan penelitian sebelumnya menurut Ika Daniarsari suhu optimum pada ekstraksi Eceng gondok adalah suhu $80^{\circ} \mathrm{C}$.

\section{DAFTAR PUSTAKA}

Andreas Sulihono, Benyamin Turihoran, Tuti Amelia Agustina., (2012) : Ekstraksi Pektin dari kulit kakao, Jurnal Teknik Kimia, Fakultas Teknik, Universitas Sriwijaya, Vol.18. No.4 
Agus Budiyanto, Yulianingsih., (2008) : Pengaruh Suhu dan Waktu Ekstraksi terhadap karakter pektin dari Ampas Jeruk Siam, Jurnal Penelitian Pascapanen Pertanian, hal 37- 44.

Farida, Hanum, Martha Angelina Tarigan, dan Irza Menka Deviliany Kaban., (2012). Ekstraksi Pektin dari kulit pisang raja. Jurnal Teknik Kimia, Universitas Sumatera Utara, Vo.1. No.2

Guichard., (1991) : Ekstraksi Pektin, Jurnal Teknik, Fakultas Teknik, Universitas Sriwijaya, Vol.16, 4, 42- 43

Hari Sutioso., (2012), : Pemanfaatan Pektin, Jurnal Teknik, Fakultas Teknik Universitas Indonesia, Jakarta

Heyne, K. (1989), Ensiklopedi Nasional Indonesia, jilid 5, PT. Cipta Adi Pustaka, Jakarta

Irwan Sofia,. (2008) Produksi Pektinase dari kulit pisang dengan jamur Aspergillus Niger, Jurusan Teknik Kimia, Institute Teknologi Bandung.

Jackson CL, Dreaden TM., (2007) : Pectin Induces Apoptosis in Human Prostate Pectin Structure Glycobiology.

Wachida, Yunianta., (2008) : Ekstraksi Pektin dari Eceng Gondok, Skripsi, Jurusan Teknologi Hasil Pertanian, Fakultas Teknologi Pertanian Universitas Brawijaya.

Widianto., (1997) : Klasifikasi Eceng Gondok, Jurnal Kimia, Vol.V, 3, 232 - 235

Winarno, F,G (2004) : Kimia Pangan dan Gizi, Gramedia, Jakarta.

W.G.T. Willat, J.Paul Knox and J.D. Mikkelesen,. (2006) : Pectin, new insight on old plymer are starting to gel. Trends in Food Science and Technology 1. 